\title{
Effect of Educational Guidelines on Nurses' Performance related to Care of Arteriovenous Fistula Puncture for Children undergoing Hemodialysis
}

\section{Riham Raafat Mahdy Aboushady ${ }^{1}$, Rahma Soliman Bahgat ${ }^{2}$, Amal Gharib Sabaq ${ }^{3}$ and Rawia Abd El-Ghany Mohammed ${ }^{4}$}

(1) Nusing Specialist, Tala Technical Secondary School For Nursing, Egypt, (2) Professor of Pediatric Nursing, Faculty of Nursing, Tanta University, Egypt, (3) Assistant Professor of Pediatric Nursing, Faculty of Nursing, Benha University, Egypt and (4) Lecturer of Pediatric Nursing, Faculty of Nursing, Benha University, Egypt

\begin{abstract}
Background: The Arterio-Venous Fistula (AVF) is the most common vascular access used in hemodialysis because AVF provides good blood flow for dialysis lasts longer than other types of access and is less likely to get infected or cause blood clots than other types of access. Educational guidelines are important for nurses working in pediatric hemodialysis units to improve children outcomes and reduce healthcare costs. Aim: This study aimed to evaluate the effect of educational guidelines on nurses' performance related to care of AVF puncture for children undergoing hemodialysis. Research design: A quasi-experimental design was utilized in this study. Setting: This study was conducted at pediatric hemodialysis unites at Benha and Menufiya University Hospitals. Subjects: A convenience sampling of 41 nurses working in the previous mentioned settings and a convenience sampling of 46 children. Tools of data collection: Two tools were used, I: Structured interviewing questionnaire and II: Observational checklists. Results: Most of the studied nurses had good level of knowledge and most of them had satisfactory level of practices after educational guidelines implementation. Conclusion: The educational guidelines was effective in improving nurses' knowledge and practices level related to care of arteriovenous fistula for children undergoing hemodialysis. Recommendations: Provision of continuous education guidelines in order to update nurses' knowledge and practices.
\end{abstract}

Keywords: Educational guidelines, Nurses' performance, Arteriovenous fistula puncture and hemodialysis.

\section{Introduction}

Kidney is one of the most important organs in the body, which is responsible for execration of waste products, regulation of body fluids and electrolytes and produce hormones. Moreover, in a healthy child the kidney works properly but when there are some defects, the kidney may be affected negatively. In Egypt, the estimated annual incidence of End Stage Renal Disease (ESRD) in children is around 74/million and the total prevalence of children on dialysis is 264/million (El-Arbagy et al., 2016).
Chronic renal failure in children is a global public health problem which tends to take dimensions of epidemic and has severe impact on quality of child's life. It is considered a progressive, irreversible deterioration in renal function in which the body's ability to sustain metabolic, fluid and electrolyte balance fails resulting in uremia (retention of urea and other nitrogenous wastes in the blood). Additionally, it is typically a progressive disease and is asymptomatic in its early stages (Kefale, 2018). 
Management for chronic renal failure in children aims to delay the progression of the disease and minimize the complications. Treatment options are dialysis or kidney transplant surgery. Kidney transplantation is the best therapy for children with ESRD. Five years survival rates in children who receive a kidney transplant are greater than survival rates of those who remain on hemodialysis or peritoneal dialysis. However, children with ESRD have special needs that differ from adults, such as the need to achieve normal growth and cognitive development. (Kliegman et al., 2016).

Hemodialysis is used to remove toxins and waste products from the blood stream by connecting the vascular access site to a dialyzer machine that works as a pump that circulates and filters the blood and returns it back into the child. Hemodialysis is achieved through vascular access, either via arteriovenous fistula, graft, or central venous catheter. Arteriovenous fistula is a connection of an artery to a vein which made in the forearm or upper arm. An arteriovenous fistula causes extra pressure and extra blood to flow into the vein making it grow large and strong. The larger vein provides easy, reliable access to blood vessels (National Kidney and Urologic Diseases Information Clearing house, 2018).

The arteriovenous fistula is preferred over the other types of access because it provides good blood flow for dialysis, lasts longer than other types of access and is less likely to get infected or cause blood clots than other types of access. There are multiple factors that may influence the survival of AVF such as age, frailty, sex, race, body mass index, smoking, timing of referral to the surgeons, surgical techniques and skills, vessel size and use of adjuvant therapies such as antiplatelet agents and infrared, timing and technique of cannulation and other diseases such as diabetes, hypotension, thrombosis, infection and aneurysm formation (Woo \& Lok, 2016).

Nurses play an important role to prolong the life span of AVF and reduce complications. Needling of arteriovenous fistula prior to hemodialysis is an important part of the hemodialysis process. Successful needling is required to perform the hemodialysis treatment using the arteriovenous fistula. Incorrect techniques can lead to complications including stenosis and aneurysm development, infections, hematoma, pseudoanuerysm, bleeding and pain. Ensuring a good technique will reduce such complications and prolong the life-span of the arteriovenous fistula (Almasri et al., 2016).

Nurses are considered to be the cause of success of the management and prevention of complications in dialysis units. The ability of nurse to minimize the access problems requires adequate education because their experience has been documented to be the most frequently related cause of vascular access complications. The development of standards of care and expertise in staff are important components to successfully prevent vascular access complications. Therefore, there is a need to establish a satisfactory level of performance for nurses working in pediatric hemodialysis units which helps in providing qualified competent nurses who providing care for children (Khalifa et al., 2017).

\section{Significance of the study}

There has been a significant rise in the prevalence of pediatric chronic kidney diseases worldwide over the past few years. This may be due to early detection of cases during childhood and longer survival of 
pediatric due to widespread availability of dialysis and transplantation. Chronic kidney disease is a worldwide public health problem; approximately $18 / 1$ million of children suffers from renal failure all over the world every year. The reported prevalence of chronic renal failure in children in Egypt is 225 / million populations (Ibrahim et al., 2019).

Incidence rate of chronic renal failure among children at pediatric hemodialysis unit in Benha university hospital is approximately 27 children in the year of 2018. While in Monefiya university hospital is 34 children in the year of 2018 (Statistical offices in Benha and Monefiya university hospital, 2018).

Indeed, vascular access is a hemodialysis child's life line, and successful cannulation is critical to its viability. One of the best ways to protect the access is to decrease cannulation attempts and needle manipulation. This will lessen the chance of infiltration and damage to the AVF wall. Nonetheless, multiple needle sticks increase the probability of vessel damage due to the development of aneurisms and infiltrations. Furthermore, provision of AVF remains the single greatest obstacles of successful hemodialysis. Hence it is crucial to use a strategy to prolong the viability of AVF (Sousa et al., 2015).

\section{Aim of the study}

The aim of the study was to evaluate the effect of educational guidelines on nurses' performance related to care of AVF puncture.

\section{Research hypothesis}

Implementation of educational guidelines was expected to increase nurses' knowledge and practices related to care of arteriovenous fistula puncture for children undergoing hemodialysis.

Subjects and Method

\section{Research design:}

A quasi experimental research design was utilized to conduct this study.

\section{Research setting:}

The current study was conducted at Pediatric Hemodialysis Units at Benha and Menufiya University Hospitals.

\section{Research subjects:}

A convenience sample of 41 nurses from the previous mentioned setting were selected regardless their characteristics.

A convenience sampling of all available children undergoing hemodialysis through AVF (46) regardless their characteristics during the period of the study.

\section{Tools of data collection:}

Data collection was gathered by using the following two tools:-

\section{Tool (I): Nurses structured interviewing} questionnaire:-It was developed by the researcher based on a review of the current relevant researches based on Khalifa et al., (2017) \& El Said, (2017) to assess nurses' knowledge related to care of AVF puncture. It consists of three parts:

Part (I): Nurses characteristics such as: Age, gender, qualification, job title, place of work, years of experience and attending training courses related to care of AVF puncture.

Part (II): Children characteristics such as: Age, gender, education, child ranking, residence consanguinity, medical history and past history.

Part (III): Nurses' knowledge: Assess nurses' knowledge related to care of arteriovenous fistula puncture for children undergoing hemodialysis. It was used twice before and immediately after the 
implementation of the educational guidelines. It consists of 29 multiple choice questions.

Nurses' knowledge scored as following: The total level of nurses' knowledge was categorized as the following:

- $75 \%$ to $100 \%$ was considered good knowledge

- $60 \%$ to less than $75 \%$ was considered fair knowledge

- Less than $60 \%$ was considered poor knowledge

Tool (II): Observational Checklists: It was adopted from Maria \& Jitka, (2014) \& Wilkinson \&Van Leuven, (2017) to assess the nurses' practice related to care of arteriovenous fistula puncture. It was used twice before and immediately after the implementation of the educational guidelines. It consists of 67 items categorized under the following:

1- Before cannulation: It includes 12 items regarding preparation of the environment (4 items), preparation of the equipment and materials (1 item), preparation of the child (3items) and assessment of AVF (4 items).

2- During cannulation: It contains 44 items divided into two subgroups. Subgroups 1: infection control practice (31 items) includes hand washing (14 items), hand scrubbing by using alcohol (3items) and sterile gloving (10items) and disinfection of AVF site (4items). Subgroup 2: cannulation technique (13 items).

3- After cannulation: It consists of 11 items regarding needle removal and hemostasis.

Scoring system for Nurses' practice was as the following:

Done correct and complete was scored (1), done incorrect or not done was scored (0).
The total level of nurses' practices was categorized as the following: $75 \%$ to $100 \%$ was considered satisfactory and $<75 \%$ was considered unsatisfactory.

\section{Ethical considerations:}

The researcher clarified the aim of the study to nurses included in the study. A written approval was obtained from each nurse to participate in the study. Nurses were assured that all gathered data was used for research purposes only and the study was harmless. Additionally, nurses were allowed to withdraw from the study at any time without giving the reason. Confidentially of the gathered data and results were secured.

\section{Reliability of tools}

Reliability for tools was applied by the researcher for testing the internal consistency of the tools by administrating the tool to the same subjects under similar conditions. Answer from repeated testing was compared (test-re-test Reliability). This turned to be (0.94) for knowledge structured interview schedule questionnaire and (0.96) for nurses' practices observational checklist, this indicate high degree of reliability for the study tools.

\section{Content validity:}

Tools of data collection were investigated for their content validity by three experts in Pediatric Nursing from Faculty of Nursing, Benha University who were selected to test the content validity of the instruments and to judge its clarity, comprehensiveness, relevance, simplicity and accuracy. The tools were regarded as valid from the experts' point of view.

\section{Pilot study:}

A pilot study was carried out to test the applicability, clarity, efficiency of the tools and to estimate the time needed for each tool. It was done on $10 \%$ of the total study 
subjects (5 nurses) who excluded in the present study to avoid sample bias and contamination. In the light of pilot study analysis, modification was done and the last form was developed.

\section{Field of work:}

The following phases were adopted to achieve the aim of the current study:-

\section{1- Assessment phase:}

This phase involved interviewing the nurses to collect baseline data. The researcher was available two days/week. At the beginning of interview; the researcher welcomed each nurse, explained the purpose, duration and activities of the study and took written approval from nurses. The data of children were collected by researcher from the medical record. The researcher gave the studied nurses questionnaire to fill it to assess their knowledge. Each nurse was observed individually during their actual practice of procedures to assess their practices by using observational checklist. This period of pretest took 4 weeks (from the beginning of September 2019 to the beginning of October 2019).

\section{2-Planning phase}

Based on baseline data obtained from pre-test assessment and relevant review of literature, the educational guidelines were developed by the researcher as indicated by nurses' level of comprehension in simple Arabic language. Different methods of teaching were used such as modified lecture, brain storming, demonstration, redemonstration and group discussion. Suitable teaching media were included hand out as well as audio-visual aids, doll and real equipment to help proper understanding of the content by nurses.

\section{3- Implementation phase:}

Guidelines were implemented through sessions. The studied nurses were divided into 8 groups each group consisted of 5-6 nurses, the program has taken 4-8 hours for each group, distributed as the following; (4) session for theoretical part each session kept going from 30-45 minutes and (4) session for practical part, each session kept going from 45-60 minutes. Each session included 10 minutes for discussion and feedback. Each session usually started by a summary of what has been taught during the previous session and the objectives of the new topics. These sessions were repeated to each group of nurses.

\section{4- Evaluation phase:}

After the implementation of the educational guidelines content, the post-test were administered to assess nurses' knowledge and practices using the same formats of pretest. This help to evaluate the effect of implemented educational guidelines. This was done immediately after the implementation of educational guidelines.

\section{Statistical analysis:}

The collected data organized, tabulated and statistically analyzed using Statistical Package for Social Science (SPSS) version. Descriptive statistics were applied (e.g. frequency, percentages, means and standard deviation). Test of significance, Chisquare test $\left(\mathrm{X}^{2}\right)$, Fisher exact test, F test, Independent $\mathrm{T}$ test and correlation coefficient (r). These tests were applied to test the study hypothesis. Reliability of the study tools was done using Cronbach's Alpha. A significant level value was considered when $p<0.05$ and a highly significant level value was considered when $\mathrm{p}<0.001$. No statistical significance difference was considered when $\mathrm{p}>0.5$. 


\section{Results:}

Table (1): Showed that $48.8 \%$ of nurses were in the age group of $25-<30$ years $\left(x^{-} \pm S D\right.$ $25.84 \pm 4.02$ years). Concerning job title, $85.4 \%$ of them were working as staff nurse and $75.6 \%$ of them working in Benha university hospital. Regarding, years of experience $48.8 \%$ of them had $4<6$ years of experience ( $\mathrm{x}^{-} \pm \mathrm{SD} 5.74 \pm 2.62$ years).

Figure (1): Demonstrated that $82.6 \%$ of nurses were females.

Figure (2): Revealed that 50\% of the studied nurses qualification was diploma of Nursing technical institute.

Figure (3): Showed that $39.1 \%$ of nurses had poor level of knowledge before educational guidelines implementation. In contrast, $80.4 \%$ had good level of knowledge after educational guidelines implementation.

Figure (4): Showed that $52.2 \%$ of the nurses had unsatisfactory practices before educational guidelines implementation .On the other hand, $91.3 \%$ had satisfactory practices after educational guidelines implementation.

Table (2): Illustrated that there was highly statistical significance relation between total knowledge of studied nurses and their educational level and years of experience before and after educational guidelines implementation ( $\mathrm{p}$-value $<0.000$ ).

Table (3): Revealed that there was highly statistical significance relation between total practices of studied nurses and their educational level and years of experience before and after educational guidelines implementation ( $\mathrm{p}$-value $<0.000$ ).
Table (4): Illustrated that there was a highly statistical significance positive relation between total knowledge scores and total practices scores of the studied nurses before and after educational guidelines implementation $\mathrm{r}=0.84, \mathrm{r}=0.42, \mathrm{p}$-value $<$ $0.000)$ respectively. 
(Table 1): Percentage distribution of the studied nurses regarding their characteristics $(n=41)$.

\begin{tabular}{|c|c|c|}
\hline Nurses' characteristics & No & $\%$ \\
\hline \multicolumn{3}{|l|}{ Age in years } \\
\hline $20-<25$ & 14 & 34.1 \\
\hline $25-<30$ & 20 & 48.8 \\
\hline $30-<35$ & 5 & 12.2 \\
\hline$\geq 35$ & 2 & 4.9 \\
\hline \multicolumn{3}{|l|}{$x^{-} \pm$SD 25.84 \pm 4.02} \\
\hline \multicolumn{3}{|l|}{ Gender } \\
\hline Male & 7 & 17.4 \\
\hline Female & 34 & 82.6 \\
\hline \multicolumn{3}{|l|}{ Qualification } \\
\hline Nursing technical school & 7 & 17.4 \\
\hline Nursing technical institute & 21 & 50.0 \\
\hline Bachelor of nursing & 13 & 32.6 \\
\hline \multicolumn{3}{|l|}{ Job title } \\
\hline Head nurse & 6 & 14.6 \\
\hline Staff nurse & 35 & 85.4 \\
\hline \multicolumn{3}{|l|}{ Place of work } \\
\hline Banha University Hospital & 30 & 73.2 \\
\hline Menufia University Hospital & 11 & 26.8 \\
\hline \multicolumn{3}{|l|}{ Years of experience } \\
\hline$<2$ & 7 & 17.0 \\
\hline $2-<4$ & 9 & 22.1 \\
\hline $4-<6$ & 20 & 48.8 \\
\hline$\geq 6$ & 5 & 12.1 \\
\hline$x^{-} \pm$SD 5.74 \pm 2.62 & & \\
\hline
\end{tabular}

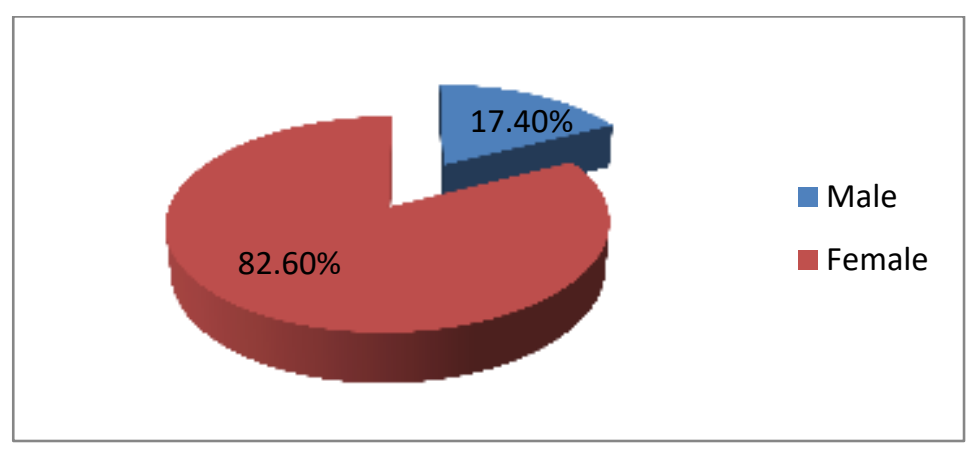

Figure (1): Distribution of the studied nurses regarding their gender $(n=41)$. 


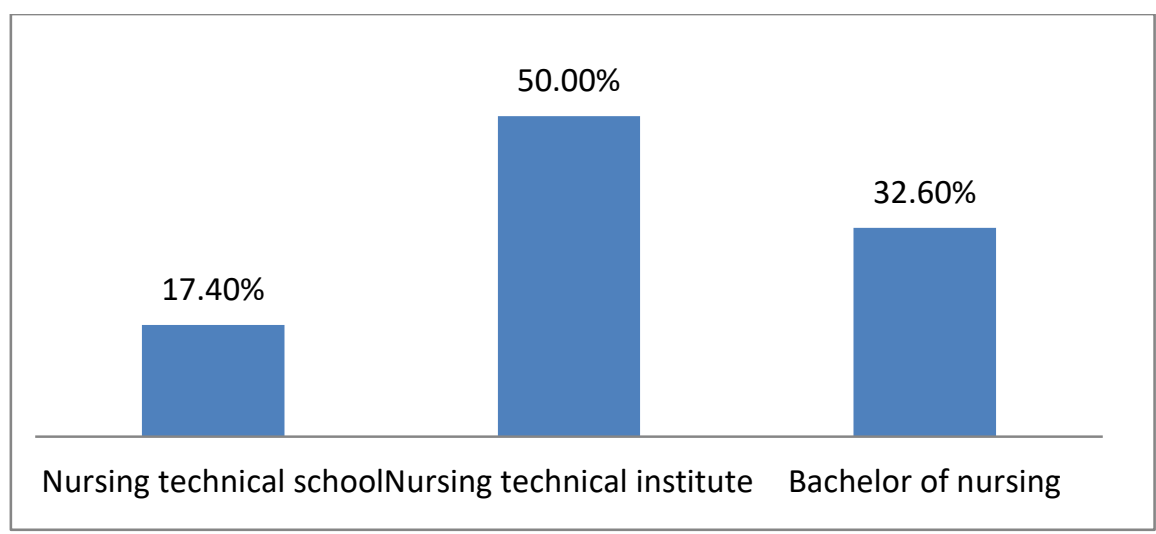

Figure (2): Distribution of the studied nurses regarding their qualification $(n=41)$.

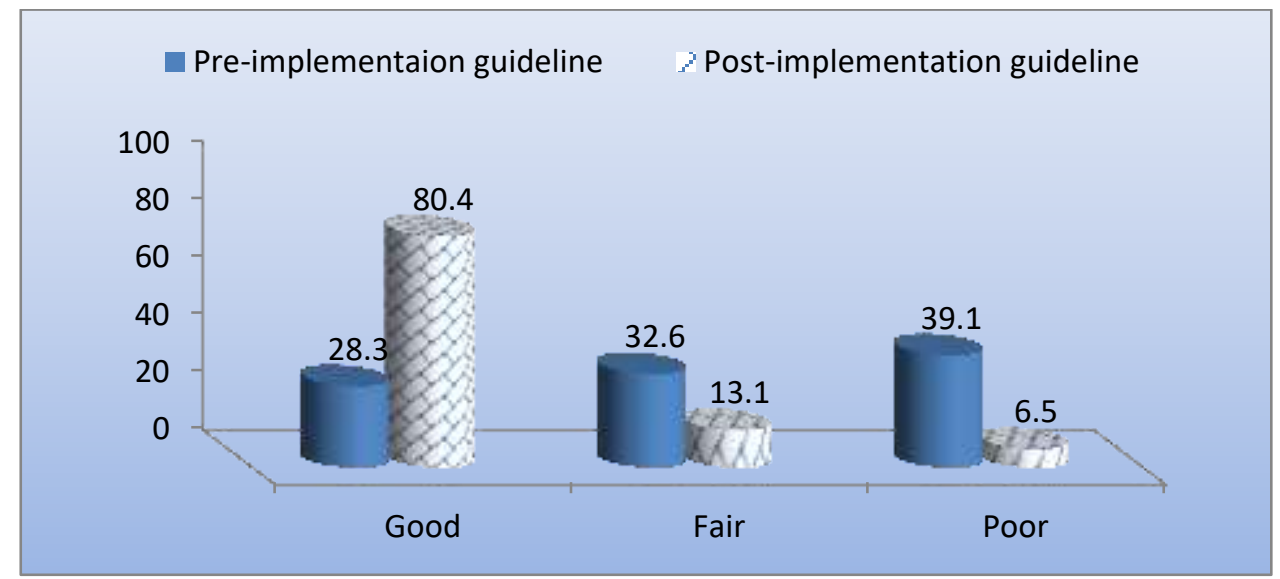

Figure (3): Distribution of the studied nurses regarding their total level of knowledge pre and post implementation of educational guidelines $(n=41)$.

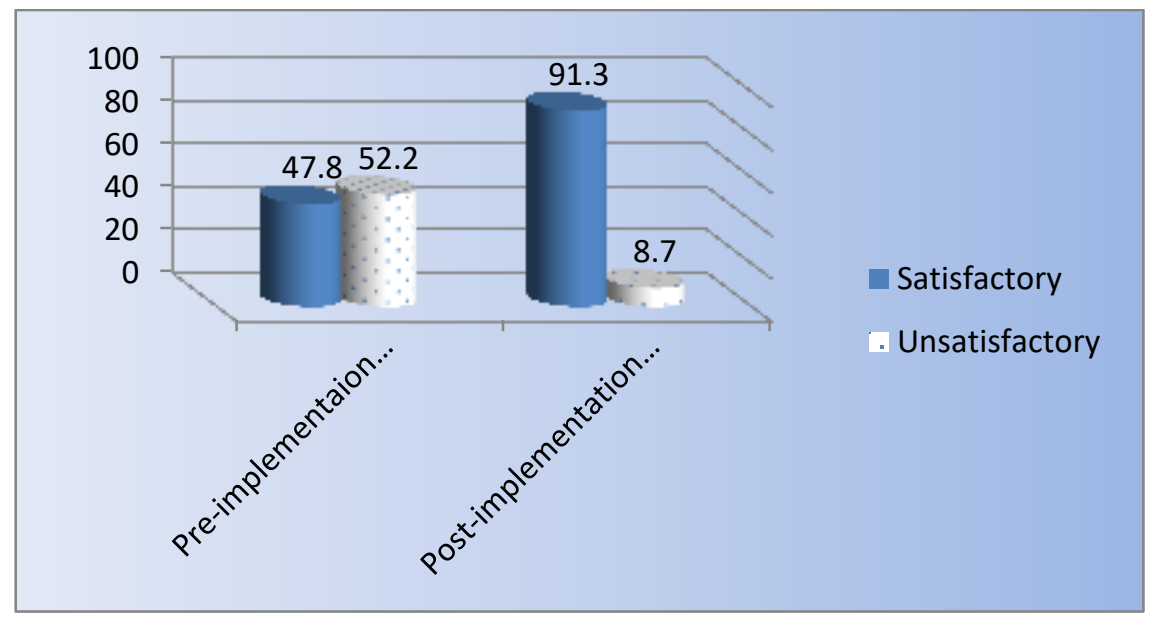

Figure (4): Distribution of the studied nurses regarding their total practices level pre and post implementation of educational guidelines. 

Fistula Puncture for Children undergoing Hemodialysis

Table (2): Relation between nurses' knowledge and their characteristics

\begin{tabular}{|c|c|c|c|c|c|c|}
\hline \multirow[t]{2}{*}{ Nurses' characteristics } & \multicolumn{2}{|c|}{$\begin{array}{c}\text { Before educational } \\
\text { guidelines } \\
\text { implementation }(n=41)\end{array}$} & \multicolumn{2}{|c|}{$\begin{array}{c}\text { After educational } \\
\text { guidelines } \\
\text { implementation }(n=41)\end{array}$} & \multirow[t]{2}{*}{$\begin{array}{c}\text { F test } \\
\text { Independent } \\
\text { T test }\end{array}$} & \multirow[t]{2}{*}{$\begin{array}{c}\text { p- } \\
\text { value }\end{array}$} \\
\hline & Mean \pm SD & $\%$ & Mean \pm SD & $\%$ & & \\
\hline \multicolumn{7}{|l|}{ Age } \\
\hline $20-<25$ years & $27.8235 \pm 7.32492$ & 36.1 & $50.1176 \pm 6.10207$ & 37.0 & 14.964 & 0.276 \\
\hline $25-<30$ years & $29.2273 \pm 8.44552$ & 49.1 & $50.3636 \pm 5.13202$ & 48.1 & 16.634 & 0.354 \\
\hline $30-<35$ years & $25.6000 \pm 7.16240$ & 9.8 & $50.2000 \pm 5.76194$ & 10.9 & 11.808 & 0.136 \\
\hline$\geq 35$ years & $33.0000 \pm 8.48528$ & 5.0 & $46.5000 \pm 10.60660$ & 4.0 & 1.976 & 0.295 \\
\hline \multicolumn{7}{|l|}{ Gender } \\
\hline Male & $25.1250 \pm 7.88194$ & 15.3 & $50.0000 \pm 7.78276$ & 17.4 & 1.351 & 0.184 \\
\hline Female & $29.1842 \pm 7.69646$ & 84.7 & $50.1053 \pm 5.19246$ & 82.6 & 0.048 & 0.962 \\
\hline \multicolumn{7}{|l|}{ Qualification } \\
\hline $\begin{array}{l}\text { Nursing technical } \\
\text { school }\end{array}$ & $29.0000 \pm 10.05698$ & 17.7 & $49.7500 \pm 6.36396$ & 17.3 & 24.318 & 0.000 \\
\hline $\begin{array}{l}\text { Nursing technical } \\
\text { institute }\end{array}$ & $28.4348 \pm 7.59082$ & 49.9 & $49.7391 \pm 5.97888$ & 49.7 & 111.807 & 0.000 \\
\hline Bachelor of nursing & $28.2667 \pm 7.35300$ & 32.4 & $50.8000 \pm 4.93095$ & 33.1 & 97.170 & 0.000 \\
\hline \multicolumn{7}{|l|}{ Years of experience } \\
\hline$<2$ years & $27.8889 \pm 8.95048$ & 17.0 & $49.5556 \pm 7.55167$ & 17.0 & 30.808 & 0.000 \\
\hline $2-<4$ years & $28.7273 \pm 6.97739$ & 22.1 & $50.6818 \pm 4.47625$ & 22.1 & 154.306 & 0.000 \\
\hline 4-<6years & $20.3400 \pm 5.23541$ & 48.8 . & $35.6781 \pm 3.26841$ & 48.8 & 26.507 & 0.000 \\
\hline$\geq 6$ years & $28.4667 \pm 8.73308$ & 12.1 & $49.5333 \pm 6.15127$ & 12.1 & 58.342 & 0.000 \\
\hline
\end{tabular}

$* *$ Highly Statistical significance (p-value $<0.000)$

Table (3): Relation between nurses' practices and their characteristics

\begin{tabular}{|c|c|c|c|c|c|c|}
\hline & \multicolumn{2}{|c|}{$\begin{array}{c}\text { Before educational } \\
\text { guidelines } \\
\text { implementation } \\
(n=41)\end{array}$} & \multicolumn{2}{|c|}{$\begin{array}{c}\text { After educational } \\
\text { guidelines } \\
\text { implementation } \\
(n=41)\end{array}$} & \multirow[t]{2}{*}{$\begin{array}{c}\text { F test } \\
\text { Independent } \\
\text { T test }\end{array}$} & \multirow[t]{2}{*}{$\begin{array}{c}\text { p- } \\
\text { value }\end{array}$} \\
\hline & Mean \pm SD & $\%$ & Mean \pm SD & $\%$ & & \\
\hline \multicolumn{7}{|l|}{\begin{tabular}{|l|} 
Age \\
\end{tabular}} \\
\hline $20<25$ years & $16.2353 \pm 5.55123$ & 33.6 & $43.8235 \pm .63593$ & 37.1 & 414.434 & 0.674 \\
\hline $25<30$ years & $18.4545 \pm 5.24384$ & 49.4 & $43.6364 \pm .84771$ & 47.7 & 494.418 & 0.513 \\
\hline $30<35$ years & $19.0000 \pm 6.85565$ & 11.4 & $44.0000 \pm .00000$ & 10.9 & 66.489 & 0.372 \\
\hline$\geq 35$ years & $22.5000 \pm 2.12132$ & 5.5 & $43.5000 \pm .70711$ & 4.3 & 176.400 & 0.126 \\
\hline \multicolumn{7}{|l|}{ Gender } \\
\hline Male & $15.3750 \pm 5.31675$ & 15.0 & $43.6250 \pm .74402$ & 17.3 & 1.425 & .161 \\
\hline Female & $18.3947 \pm 5.47001$ & 85.0 & $43.7632 \pm .71411$ & 82.7 & 0.494 & .624 \\
\hline \multicolumn{7}{|l|}{ Education } \\
\hline $\begin{array}{l}\text { Nursing technical } \\
\text { school }\end{array}$ & $17.0000 \pm 5.50325$ & 16.5 & $43.7500 \pm .46291$ & 17.4 & 187.689 & .000 \\
\hline $\begin{array}{l}\text { Nursing technical } \\
\text { institute }\end{array}$ & $16.7826 \pm 5.41846$ & 47.0 & $43.7826 \pm .59974$ & 50.0 & 564.178 & .000 \\
\hline Bachelor of nursing & $20.0000 \pm 5.38516$ & 36.5 & $43.6667 \pm .97590$ & 32.6 & 280.501 & .000 \\
\hline \multicolumn{7}{|l|}{ Years of experience } \\
\hline$<2$ years & $15.0000 \pm 5.87367$ & 17.0 & $\begin{array}{l}43.8889 \pm .78174 \\
436364+84771\end{array}$ & 17.0 & 213.924 & 0.000 \\
\hline $2-<4$ years & $18.7727 \pm 5.09838$ & 22.1 & $\begin{array}{c}43.6364 \pm .847 / 1 \\
156781\end{array}$ & 22.1 & 509.147 & 0.000 \\
\hline 4-<6years & $20.3400 \pm 6.23541$ & 48.8 & $\begin{array}{l}45.6 / 81 \\
+26841\end{array}$ & 48.8 & 426.507 & 0.000 \\
\hline$\geq 6$ years & $18.2667 \pm 5.66274$ & 12.1 & $\begin{array}{c} \pm 20841 \\
43.8000 \pm .41404\end{array}$ & 12.1 & 303.345 & 0.000 \\
\hline
\end{tabular}

** Highly Statistical significance $(\mathrm{p}$-value $<0.000)$ 
Table (4): Correlation between total knowledge and total practices before and after educational guideline implementation $(n=41)$

\begin{tabular}{||c|c|c|c|c|}
\hline \multirow{2}{*}{} & \multicolumn{4}{|c|}{ Total Knowledge scores } \\
\cline { 2 - 5 } & \multicolumn{2}{|c|}{$\begin{array}{c}\text { Before educational guidelines } \\
\text { implementation }(\mathbf{n}=\mathbf{4 1})\end{array}$} & $\begin{array}{c}\text { After educational guidelines } \\
\text { implementation }(\mathbf{n}=41)\end{array}$ \\
\cline { 2 - 5 } & $\mathrm{r}$ & $\mathrm{p}$-value & $\mathrm{r}$ & $\mathrm{p}$-value \\
\hline Total Practices scores & 0.84 & $0.000^{* *}$ & 0.42 & $0.003^{* *}$ \\
\hline
\end{tabular}

** Correlation is significant at the 0.01 level (2- tailed).

\section{Discussion}

Educational guidelines are important for nurses working in pediatric hemodialysis units to improve children outcomes and reduce healthcare costs. It is essential that everyone involved in caring for children with a vascular access device is educated about care of arteriovenous fistula. Nurses need to be confident and proficient in care of arteriovenous fistula. Well-organized educational guidelines that enable nurses to provide, monitor, and evaluate care and to continually increase their knowledge and improve their practices (National Institute for Health and Care Excellence, 2018).

Regarding to characteristics of the studied nurses as showed in table (1), it was cleared $\mathrm{x}^{-} \pm \mathrm{SD}$ was $25.84 \pm 4.02$ years. This finding disagreed with Yousif et al., (2017) in a study entitled "The effect of an educational program for vascular access care on nurses' knowledge in Khartum state" who showed that $x^{-} \pm S D$ was $34.31 \pm 6.59$ years. This could be due to the demanding nature of dialysis service so that older nurses may find it difficult to cope with the load of work required.

Related to gender of the studied nurses according to figure (1), the majority of the nurses were females. This result was in the same line with Ibrahim et al., (2019) in a study entitled "Assessment of nurses' performance regarding care of children undergoing hemodialysis therapy" who reported that more than three quarters (78\%) of the studied nurses were females. While this finding is in disagreement with Bakey, (2014) in a study entitled "Evaluation of nurses practices throughout hemodialysis treatment for patients in hemodialysis unit at Baghdad teaching hospitals " in Iraq who stated that less than half $(46.7 \%)$ of studied nurses were females. This reflects the general nursing situation in Egypt where most of the nursing is carried out by females and may also related to the studying of nursing in Egyptian universities were exclusive for females only till few years ago.

Concerning nurses' education according to figure (2), half of the studied nurses had nursing technical institute degree. This finding came on the same line with AlMawsheki, (2016) in a study entitled "Nurses' knowledge and practice regarding care for the patients during hemodialysis" who reported that more than one half $(58 \%)$ of studied nurses had technical institute degree. The findings of this study might be due to the fact that the nursing technical institute provided the community with a large number of the nursing graduates than the other agencies such as the faculties of nursing.

Regarding years of experience according to table (1), $\mathrm{X}^{-} \pm \mathrm{SD}$ was $5.74 \pm 2.62$. This finding agrees with Yousef et al., (2019) 
in a study entitled "The effect of educational program on knowledge and practices of nurses regarding infection control measures for children under hemodialysis" who found that the $\mathrm{x}^{-} \pm \mathrm{SD}$ was $6.53 \pm 2.98$. This could be due to that nurses in pediatric hemodialysis unit require more years of experience to have good knowledge and practice regarding care of arteriovenous fistula.

According to figure (3) the findings of the current study highlighted that, less than two fifth of the studied nurses had poor level of knowledge before educational guidelines implementation. The finding of this study is congruent with Saleh et al., (2018) in a study entitled "Nurses compliance to standards of nursing care for hemodialysis patients" who mentioned that more than two fifth $(41.5 \%)$ of studied nurses had unsatisfactory knowledge level at the preprogram phase. This could be due to the fact that all nurses did not attend any training courses related to care of arteriovenous fistula (AVF) for children undergoing hemodialysis, the lack of nurses' incentives and desire to enhance or at least refresh their knowledge whether new or old graduated nurses as well as the work overload.

The current study found that, the majority of nurses had good level of knowledge after educational guidelines implementation with a highly statistical significant difference between pretest and posttest ( $\mathrm{P}<0.000)$. This finding was paralleled with Yousef et al., (2017) who revealed that three quarters $(75 \%)$ of nurses had good level of knowledge in the post implementation phase and there were highly statistical significant differences between pretest and posttest ( $\mathrm{P}<0.001)$. This improvement indicated that the educational guidelines were a successful method to increase nurses' knowledge.
According to figure (4), the findings of the current study highlighted that, more than half of the studied nurses had unsatisfactory practices level before educational guidelines implementation. This result was inconsistent with Ibrahim et al., (2019) who cleared that, more than half $(56 \%)$ of the studied nurses had incompetent practice regarding care of child undergoing hemodialysis therapy. But this finding was in disagreement with AlMawsheki et al., (2016) who showed that more than half of studied nurses $(56 \%)$ had satisfactory level of practice regarding care in hemodialysis therapy. This might be due to the lack of nurses' application of knowledge especially regarding nursing interventions with common complications that occur and misunderstanding of their roles as there is no job description or definition of responsibilities in the hemodialysis unit.

The current study showed that the majority of nurses had satisfactory practices in the post implementation phase with highly statistical differences between pretest and posttest $(p<0.000)$. This finding agree with Saleh et al., (2018) who found that the majority $(80.9 \%)$ of them had satisfactory practices in the post implementation phase with a highly statistical significant differences between pre -test and post- test $(\mathrm{p}<0.001)$.

Regarding relationship between the total level of nurses' knowledge and their characteristics according to table (2), the present study showed that there was highly statistical significant relation between total knowledge of nurses and their qualification and years of experience before and after educational guidelines implementation. This result disagree with Ahmed \& Mohamed, (2019) in a study entitled " Effect of educational program about infection control precautions for nurses in pediatric 
hemodialysis units" whose results showed that there was no statistical significant relation between nurses' total level of knowledge and their education and years of experience in the pre and post implementation phase. This could be due to nurses with more years of experience proved to have better knowledge than those with shorter experience.

Concerning relationship between the nurses' total level of practice and their characteristics according to table (3), the present study showed that there was highly statistically significant relation between total practices of nurses and their qualification and years of experience before and after educational guidelines implementation. This result agree with Bayoumi \& Mahmoud, (2017) in a study entitled " Effect of education program on nurses' knowledge and practice regarding care of central venous line in pediatric hemodialysis: evidence-based practice guidelines" who showed that there was a highly statistically significant relation between nurses' practice and their educational level and years of experience at pre implementation phase and immediately after implementation. This could be due to nurses with longer years of experience had better practice about care of AVF puncture for children undergoing hemodialysis than the less experienced nurses. Also day to day activities enhances nurses' experiences and improve their practices. Additionally, education is a potential means for implementing prevention strategies as it alters perception, increases knowledge and in turn changes work practice.

As regarding to studying the correlation between studied nurses' total knowledge and total practices regarding care of AVF puncture for children undergoing hemodialysis therapy according to table (4), the current study revealed that there was highly Statistical significance positive correlation between total knowledge and total practices of the studied nurses before and after educational guidelines implementation. This result was convenient with Saleh et al., (2018) who found that there was a strong positive correlation $(\mathrm{p}<0.001)$ between nurses' total knowledge and their total practice. Meanwhile, this result disagreed with Ibrahim et al., (2019) who illustrated that there was no statistically significant relation ( $\mathrm{p}>0.05)$ between nurses' knowledge and practice in their study. This might be due to knowledge is the baseline for the practices.

\section{Conclusion}

The educational guidelines was effective in improving nurses' knowledge and practices level related to care of arteriovenous fistula puncture for children undergoing hemodialysis. Besides, there was a highly statistical significant positive correlation between nurses' total knowledge and practices level related to care of arteriovenous fistula puncture for children undergoing hemodialysis before and after the educational guidelines implementation.

\section{Recommendations}

Provision of continuous education guidelines in order to update nurses' knowledge and enhance their practices related to care of arteriovenous fistula puncture for children undergoing hemodialysis.

\section{Further researches:}

An educational program for the parents and children related to care of hemodialysis vascular access must be conducted. 


\section{References}

Ahmed S. \& Mohamed A. (2019). Effect of educational program about infection control Precautions for nurses in pediatric hemodialysis units, Minia Scientific Nursing Journal, 4 (1): 77-88.

Almasri J., Alsawas M., Mainou M. \& Mustafa R. (2016). Outcomes of vascular access for hemodialysis: A systematic review and meta-analysis, Journal of Vascular Surgery, 64(1): 236-243.

Al-Mawsheki E., Ibrahim M. \& Taha N. (2016). Nurses' knowledge and practice regarding care for the patients during hemodialysis, Medical Journal of Cairo University, 84(1): 1135-1141.

Bakey S. (2014). Evaluation of nurses' practices throughout hemodialysis treatment for patients in hemodialysis unit at Baghdad teaching hospitals, Kufa Journal for Nursing sciences, 2 (2): 64-76.

Bayoumi M. \& Mahmoud N. (2017). Effect of education program on nurses' knowledge and practice regarding care of central venous line in pediatric hemodialysis: evidence-based practice guidelines, Egyptian Nursing Journal, 14(2): 87-99.

El-Arbagy, A., Yassin, Y. \& Boshra, B. (2016). Study of prevalence of end-stage renal disease in Assiut governorate, Menoufia Medical Journal, 29(2), 222-227.

El-Said R. (2017). Effect of cryotherapy on pain intensity at puncture sites of arteriovenous fistula for children undergoing hemodialysis therapy. PHD thesis, Faculty of Nursing, Pediatric Nursing Department, Benha University.

Ibrahim M., Ouda W. \& Ismail S. (2019). Assessment of nurses' performance regarding care of children undergoing hemodialysis therapy, Egyptian Journal of Health Care,10(3) :113-125.
Kefale B. (2018). Current management of chronic kidney disease, Journal of Urology and Nephrology ,6 (2): 2476-0552

Khalifa M., Okby O. \& Fathala A. (2017). Nurses' knowledge and performance about maintenance and prevention of vascular access complications in pediatric hemodialysis units, Journal of Nursing and Health Science (6): 78-99.

Kidney, Urologic Diseases Information Clearing House (2018). Vascular access for hemodialysis, Available at www.kidney. niddk.nih.gov, Accessed: 31/7/2019, 12 P.M.

Kliegman R. Stanton B., Geme J., Sehor N. \& Behrman R. (2016). Nelson text book of pediatrics, $20^{\text {th }}$ edition, chapter 536, page 2547, Elsevier publishers, Pennsylvania.

Maria T. \& Jitka P. (2014). Vascular access cannulation and care. A nursing best practice guide for arteriovenous fistula , $1^{\text {st }}$ edition, Chapter 8, page 50-60 Fresenius Medical care, Madrid.

National Institute for Health and Care Excellence, (2018). Preventing infection related to vascular access preventing infection related to vascular access Devices, Available at

http://pathways.nice.org.uk/pathways/preventi on- and-control-of-health care associatedInfections, Accessed: 24/12/2020, 3 P.M.

Saleh M., Ali J. \& Afifi W. (2018). Nurses compliance to standards of nursing care for hemodialysis patients: educational and training intervention, Nursing and Health Science Journal, 7(2): 48-60.

Sousa C., Figueiredo M., Dias V., Teles P. \& Apóstolo J. (2015). Construction and validation of a scale of assessment of selfcare Behaviors anticipatory to creation of arteriovenous fistula , Journal of Clinical Nursing 24: 3674-80 
Statistical office at Benha university hospital and Monefiya university hospital (2018)

Wilkinson \& Van Leuven (2017). Procedure checklists for fundamentals of Nursing, Available at https://fliphtml5.com/ixbs/ftge, Accessed: 10-2-2019, 2 P.M.

Woo K. \& Lok C. (2016). New insights into dialysis vascular access: what is the optimal vascular access type and timing of access creation in chronic kidney diseases and dialysis patients? Clinical Journal of American Society Nephrol, 11(8): 1487-94.

Yousef Y., Elashir U., Mahmoud S. \& Maghraby N. (2019). The effect of educational program on knowledge and practices of nurses regarding infection control measures for children under hemodialysis. Egyptian Nursing Journal, 16(1): 1-9.

Yousif K., Hassan A. \& Abboud O. (2017). The effect of an educational program for vascular access care on nurses' knowledge in Khartum state, Saudi Jjournal of Kidney Diseases and Transplantation, 28(5): 10271033. 
تأثير الإرشادات التعليمية علي أداء الممرضات تجاه رعاية وخز الوصلة الثرياتية الوريدية للأطفال الخاضعين للغسيل الدموي

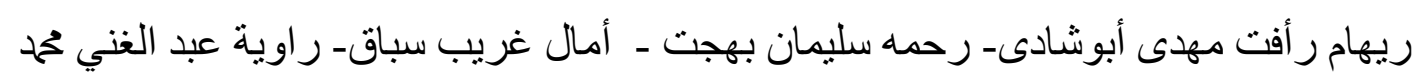

تعثبر الوصلة الثريانية الوريدية هي الطريقة الأكثر إستخداما في الغسيل الدموي، وعدد الأوعية الدموية

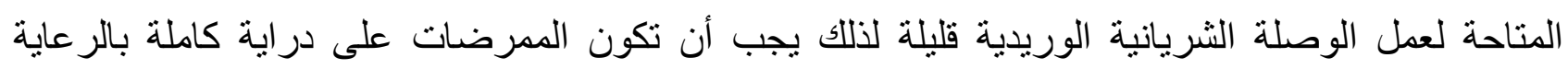

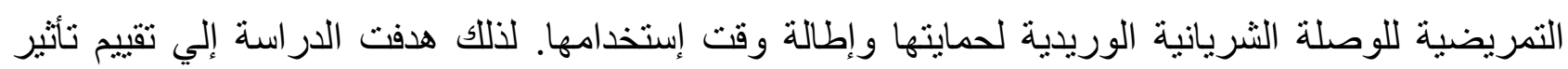

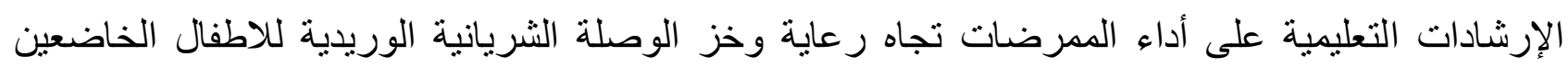

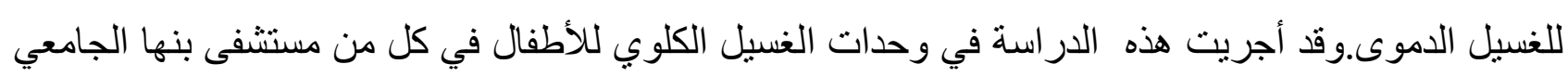

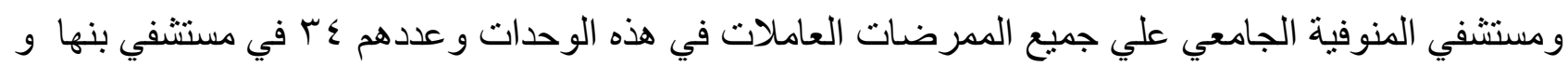

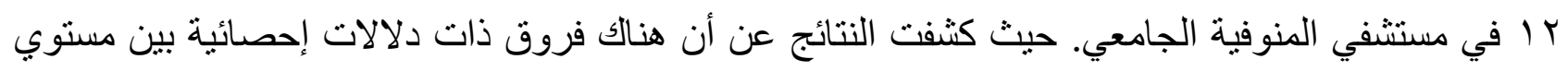

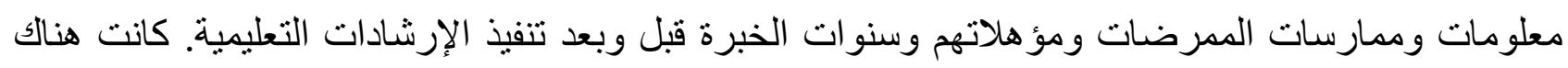

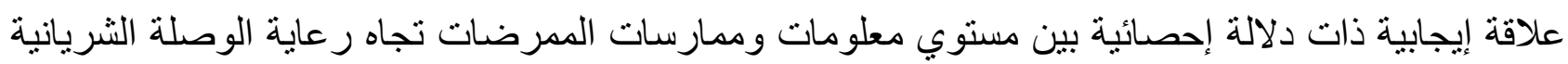

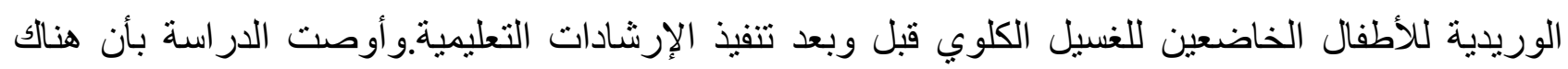
حاجة إلي تنفيذ برامج توجيهية للممرضات العاملات في وحدات الغسيل الكلوي للأطفال لتحديث مسنوي

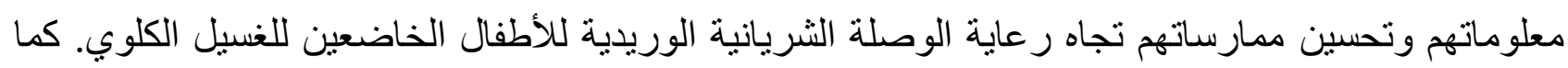
أوصت بعمل برامج تعليمية للو الدين و الأطفال تجاه رعاية الأو عية الدموية المستخدمة في الغسيل الدموي. 